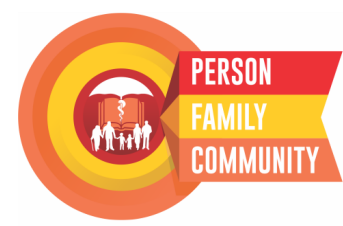

Journal Homepage:

https://jurnal.ugm.ac.id/rpcpe

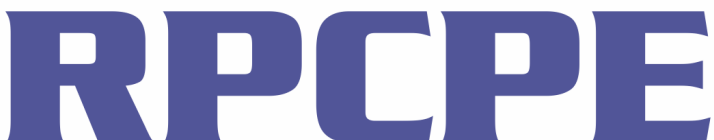

ISSN 2613-943X (print) ISSN 2620-5572 (online)

Review of Primary Care Practice and Education (Kajian Praktik dan Pendidikan Layanan Primer)

\title{
Knowledge, Attitude, and Practice of Malaria Community Worker towards Prevention and Control of Malaria in Kokap, Kulon Progo: A Pilot Study
}

\author{
Noor Afif Mahmudah¹, Esaputri Intan³ ${ }^{3}$ Bayuangga Halwan Fuad², Budi Nova Yuli Prasetyo², Kurniawan Alif ${ }^{4}$, Daud Ditha \\ Marissya $^{2}$, Haposan Jonathan Hasian ${ }^{2}$
}

\author{
${ }^{1}$ Department of Family and Community Medicine; Faculty of Medicine, Public Health and Nursing; Universitas Gadjah Mada; \\ Indonesia \\ ${ }^{2}$ Faculty of Medicine; Public Health and Nursing; Universitas Gadjah Mada; Indonesia \\ ${ }^{3}$ Department of Nutrition; Faculty of Medicine, Public Health and Nursing; Universitas Gadjah Mada; Indonesia \\ ${ }^{4}$ Faculty of Veterinary; Universitas Gadjah Mada; Indonesia
}

Correspondence Author:

Noor Afif Mahmudah: Department of Family and Community Medicine, Faculty of Medicine, Public Health and Nursing, Universitas Gadjah Mada, Yogyakarta, Indonesia. Jalan Farmako, Sekip Utara, Yogyakarta 55281, Indonesia

E-mail: afi.mahmudah@gmail.com

\begin{abstract}
Background: Malaria Community Worker (CMW) has a crucial role in malaria prevention and control in the community. However, a number of studies showed that there is a lack of competence from MCW in carrying out its duties. Knowledge, attitudes and practice (KAP) can represent the behavior about health services. Objective: This study aimed to assess the knowledge, attitudes and practice of the Malaria Community Worker towards prevention and control of malaria in Kokap, Kulon Progo. Methods: KAP survey with cross-sectional design was conducted in this study. CMW from Puskesmas Kokap I (n = 8) was asked to fill out a KAP questionnaire. Descriptive statistics and inferential tests were used to analyze the data. Data were analyzed by IBM SPSS Statistics Version 25. Results: The study found that $100 \%$ of respondents $(n=8)$ obtained high knowledge scores with the highest aspect on understanding about malaria and the lowest on diagnosis. The attitude score showed a moderate attitude for $100 \%$ of respondents $(n=8)$ with the highest aspect was fogging for malaria prevention and the lowest was the attitude that malaria is a serious disease. Meanwhile, the score of practice described good practice in $100 \%$ of respondents $(\mathrm{n}=8)$ with the lowest part was compiling daily/weekly reports to the malaria program coordinator of Primary Health Care. From the observations, there was no significant correlation $(\mathrm{p}>0.05)$ between demographic characteristics and between knowledge, attitudes and practice. Conclusion: The CMWs had a high knowledge score, moderate attitude, and good practice towards malaria prevention and control. Further studies with a larger sample are recommended for future study. CMW training is also recommended to improve the KAP of CMW.
\end{abstract}

\section{Keywords: Malaria; Community Health Cadre; Knowledge; Attitude; Practice}

\section{BACKGROUND}

Malaria is a disease with a high mortality risk for infants, toddlers and pregnant women. Since 2010, the Ministry of Health of the Republic of Indonesia (MoH RI) has launched a malaria eradication program with a target of elimination by 2030 . The malaria morbidity rate (Annual Parasite Insidence/API) in Indonesia have been reduced from 2009 to 2018. In 2018, The API rate for malaria in the Special Region of Yogyakarta (Daerah Istimewa Yogyakarta/DIY) is 0.01 per 1,000 population ${ }^{1}$. The incidence of malaria in DIY Province only occurs in Kulon Progo Regency with the most cases in Kokap Subdistrict ${ }^{2,3}$.

A number of prevention and control programs to eliminate malaria have been implemented. Referring to the Malaria Community Program launched by WHO, increasing community capacity is fundamental to preventing and reducing the incidence of malaria. A systematic review study showed that health cadres from the community have an essential roles in prevention, promotion, and case management in malaria interventions, including the Malaria Community Worker ${ }^{4}$. Malaria Community Worker (MCW) is a health cadre from the community which led by the head of the local Puskesmas and the closest health workers to the community $^{5}$. MCW has a variety of tasks, including active and passive patient detection, epidemiological surveillance, and vector control ${ }^{6}$.

Knowledge, attitudes and practice survey (KAP) represent a specific population to gather information about what knowledge is known, believed, and carried out on a particular topic. Knowledge is assessed to find out how far the population understands the biomedical concept. Questions about knowledge usually include the causes and symptoms of a disease. Attitude is a learned predisposition to think, feel, and act in a certain way towards an object. This attitude is the product of a complex interaction between beliefs, feelings, and values. Practice in KAP surveys is usually assessed by the health care measures which taken ${ }^{7}$.

As previously explained, $\mathrm{MCW}$ has an important role in malaria prevention and control in the community. MCW as the spearhead of malaria management in community need to have various abilities and competencies to carry 
out its role. These include: thin smear of peripheral blood for malaria diagnosis, good communication skills to identify a patient's history of malaria and patient education. However, a number of studies have shown that there were some deficiencies in MCW's competence in carrying out this function. A study in Kulon Progo Regency regarding the evaluation of Malaria Community Workers showed that only $8.3 \%$ of cadres took samples of peripheral blood smears based on clinical symptoms, and only $4.2 \%$ of cadres were able to examine thin blood smears with the right technique ${ }^{8}$. Another study in Purworejo Regency also stated that there were several program implementations by MCW that were not following the guidelines?.

Malaria prevention and control by MCW is proportional to its KAP scores. Therefore, KAP study is important to know how the knowledge, attitudes, and practice of MCW towards malaria prevention and control. However, within the author's knowledge, KAP survey towards malaria prevention and control for MCW has not been conducted Indonesia. Therefore, this KAP survey is needed to assess the knowledge, attitudes and practice of MCW towards malaria prevention and control, so that this information can be used to develop better programs and strategies to increase MCW's knowledge and competences in carrying out its duties.

\section{OBJECTIVE}

This study aimed to assess the knowledge, attitudes and practice of the Malaria Community Worker towards malaria prevention and control in Kokap, Kulon Progo.

\section{METHODS}

\section{Design, setting, and sample of study}

This research was a pilot study of KAP survey using a questionnaire with a cross-sectional analysis design. The study was conducted from August 2016 - May 2017 in Kokap District, Kulon Progo. The study population was the Malaria Community Worker (MCW). Through the purposive sampling method, all MCWs with the total number of 8 participants from the Kokap 1 Primary Health Care (PHC) were involved as study participants. Kokap 1 PHC was chosen due to the highest number of malaria cases in Kulon Progo regency ${ }^{2}$. The survey questionnaire was distributed at the Kokap 1 PHC where participants were asked to answer the questionnaire on the spot and collected immediately upon completion.

\section{Study Instrument}

The questionnaire was developed through an in-depth literature review on malaria and the duties and roles of the Malaria Community Worker in prevention and control of malaria. The questionnaire which comprising of four sections and a total of 54 question items in Bahasa Indonesia was used in data collection. The first three parts of the form were self-administrated questionnaire, while the last part was filled out by the interviewer. The first part was about demographic data of respondent with total of 8 questions. The second part assessed the knowledge about malaria including definition, etiology, transmission, symptoms, diagnosis, treatment, prevention and the main functions of MWC, which consists of 30 questions. Each question was a multiple choice of 'true' or 'wrong'. The questionnaire points ranges were 30 (maximum) and 0 (minimum). The total points of questionnaire then converted into a knowledge score of 0 (all wrong) to 100 (all correct). The knowledge score then ranked into high (71-100), moderate $(51-70)$, and low $(\leq 50)$.

The third section assessed attitudes towards malaria with a total of 10 questions. Each question consists of 4 ranges of attitudes, namely: strongly agree, agree, disagree, and strongly disagree. The point for each question ranges from negative attitudes (minimum 1) to positive (maximum $4)$. The total points then converted into a score of 0 100. Attitude score then classified into excellent $(>60)$, moderate (31-60), and poor (0-30).

Meanwhile, the last section assesses the practice of MCW on malaria prevention and control. The first question contains 19 sub questions about making blood samples that meet the requirements according to the procedure. Participants were asked to practice making blood samples on the spot and assessed whether the steps were in accordance with the procedure. The next six (6) questions asked about the duties as MCW carried out so far. Each question consists of a multiple choice of 'yes' and 'no'. The behavioral score ranges from 0 (minimum) to 100 (maximum). The scores obtained then grouped as excellent (71-100), moderate (51$70)$ and poor $(\leq 50)$.

\section{Data Analysis}

Descriptive statistics were used to illustrate the demographic characteristics of the respondents. Categorical variables were expressed as percentages, while numeric variables were measured as mean and standard deviation. The Kolmogorof Smirnov normality test was carried out to see the distribution of normality data. The Mann Whitney and Kruskal Wallis test was applied to assess differences of demographic variables. The assumptions for those tests were assessed and fulfilled. The Spearman test was used to evaluate the relationship between variables. The p-value $<0.05$ was taken as a significant level for the inferential and Spearman tests. IBM SPSS Statistics version 25 was used for data analysis.

\section{RESULTS}

\section{Demographic characteristics}

A total of 8 respondents were obtained with the demographic characters shown in Table 1. Based on the results of the Kolmogrov-Smirnov normality test, it is known that the data is not normally distributed. The gender of all respondents is male. The mean age of the respondents was $44.25 \pm 7.32$ with an age range of $35-56$ years. The majority of respondents have an education level of Primary and Secondary School (62.5\%) and a family income of $<$ IDR 1.100 .000 (equivalent to 73.7 USD) $(62.5 \%)$. In addition, the majority of respondents also have been worked as MCWs for 0-10 years (50\%) and joined previous training for MCWs within 2 years ago $(62.5 \%$,). The mean of experience working as MCW was $13.1 \pm \mathbf{1 0 . 3}$ with minimum of 2 years to maximum of 32 years. 
Table 1. Characteristics of respondents $(\mathrm{N}=8)$

\begin{tabular}{|c|c|c|}
\hline Characteristics & $\mathbf{N}$ & $\%$ \\
\hline \multicolumn{3}{|l|}{ Age $(44.25 \pm 7.32)$} \\
\hline $30-39$ & 2 & 25 \\
\hline $40-49$ & 4 & 50 \\
\hline$\geq 50$ & 2 & 25 \\
\hline \multicolumn{3}{|l|}{ Gender } \\
\hline Male & 8 & 100 \\
\hline Female & 0 & 0 \\
\hline \multicolumn{3}{|l|}{ Level of Education } \\
\hline Primary-secondary school & 5 & 62.5 \\
\hline Tertiary school & 2 & 25 \\
\hline \multicolumn{3}{|l|}{ Family Income } \\
\hline$<$ IDR $1,100,000$ & 5 & 62.5 \\
\hline$\geq \operatorname{IDR} 1,100,000$ & 2 & 25 \\
\hline \multicolumn{3}{|c|}{ Experience working as MCWs } \\
\hline $0-10$ years & 4 & 50 \\
\hline $11-20$ years & 3 & 37.5 \\
\hline$>20$ years & 1 & 12.5 \\
\hline \multicolumn{3}{|c|}{ Previous Training for $M C W s$} \\
\hline Within 1 year & 2 & 25 \\
\hline Within 2 years & 5 & 62.5 \\
\hline Within 3 years & 4 & 50 \\
\hline
\end{tabular}

\section{Assessment of knowledge of MCW towards malaria prevention and control}

Table 2 describes the results of the participants' responses to knowledge about malaria prevention and control. Of the 8 respondents, $100 \%(n=8)$ had high knowledge. The lowest mean knowledge scores were found in the diagnosis $(58 \pm 24)$, symptoms (63 \pm 21$)$, and MCW main tasks (67 $\pm 21)$. Meanwhile, the highest mean knowledge score was the definition of malaria $(96 \pm 12)$.

Table 2. Responses to malaria prevention and control knowledge items

\begin{tabular}{ll}
\hline Knowledge items (range of point) & Score (Mean \pm SD) \\
\hline Definition (0-3) & $96 \pm 12$ \\
Etiology (0-4) & $88 \pm 19$ \\
Transmission (0-3) & $67 \pm 18$ \\
Symptoms (0-3) & $63 \pm 21$ \\
Diagnosis (0-3) & $58 \pm 24$ \\
Treatment (0-5) & $85 \pm 18$ \\
Prevention (0-3) & $92 \pm 15$ \\
Duties of MCW (0-6) & $67 \pm 18$ \\
Total & $77 \pm 5.6$ \\
\hline
\end{tabular}

Note: Knowledge was assessed by giving 1 to correct answer and 0 to the wrong answer. The point measured knowledge from maximum 30 to minimum 0. Total points then converted to score of 0-100.

\begin{abstract}
Assessment of attitude of MCW towards malaria prevention and control

MCW's attitude towards malaria prevention and control was assessed by asking 10 questions as shown in Table 3. Out of a total of 8 respondents, $100 \%$ had moderate attitudes with a mean score of $52 \pm 3.4$. The three lowest mean score for attitudes were that malaria is a serious health problem $(28 \pm 8.8)$, a good blood samples can make malaria diagnosis easier $(31 \pm 12)$, and malaria can heal itself without treatment $(44 \pm 26)$. Meanwhile, the highest average attitude value was fogging is the most appropriate way to prevent malaria $(69 \pm 22)$.
\end{abstract}

\section{Assessment of practice of MCW towards malaria prevention and control}

The MCW practice assessment towards malaria prevention and control consisted of the practice of thin blood smears and the implementation of other tasks as MCW. Of the 8 respondents, $100 \%$ had excellent practice score with mean of $90 \pm 5.4$. The lowest score of MCW's practice regarding malaria prevention and control was to compiling daily / weekly report to the Manager of Malaria Program in PHC $(25 \pm 46)$. Whereas, the tasks include visiting each house according to a set schedule to early detect malaria cases, providing information if there is population migration / exodus arrivals from outside Java, assisting the malaria treatment based on instructions from the PHC, and being present at the PHC at least once a month were the highest score with a mean of $100 \pm 0$ (Table 4).

\section{Association of demographic characteristics and mean} KAP scores

Table 5 presents the relationship between demographic characteristics and the average KAP score. From research observations, there was no significant association between demographic characteristic variables and the mean KAP 
Table 3. Responses to malaria prevention and control attitude items

\begin{tabular}{ll}
\hline Items of attitudes (range points) & Score (Mean \pm SD) \\
\hline Malaria is a life-threatening disease (1-4) & $28 \pm 8.8$ \\
Malaria can self-heal without treatment (1-4) & $44 \pm 26$ \\
Malaria prevention measures are taken if there are already malaria cases in the neighborhood (1-4) & $50 \pm 23$ \\
A good blood samples (meeting the requirements) can facilitate the diagnosis of malaria (1-4) & $31 \pm 12$ \\
Fogging is the best approach to malaria prevention (1-4) & $69 \pm 22$ \\
MCW resources are not needed in non-malaria endemic areas (1-4) & $59 \pm 23$ \\
Blood draws by MCW is only for patient with fever (1-4) & $66 \pm 19$ \\
MCW conducts home visits at least once a month (1-4) & $50 \pm 23$ \\
MCW is not entitled to give health education (1-4) & $63 \pm 19$ \\
MCW's duties was simply to send blood samples to the Puskesmas (1-4) & $63 \pm 19$ \\
\hline Total & $52 \pm 3.4$ \\
\hline
\end{tabular}

Note: The point for each question ranges from negative attitude (minimum 1) to positive (maximum 4). The attitude point ranges from maximum 40 to minimum of 0 . The total points then converted into a score of 0-100.

Table 4. Responses to malaria prevention and control practice items

\begin{tabular}{ll}
\hline Items of practice (range point) & Score (Mean \pm SD) \\
\hline Make a good blood samples (meet the requirements) according to the procedure (0-19) & $91 \pm 5.6$ \\
Visiting each house according to the schedule set to make early detection of malaria & $100 \pm 0$ \\
& \\
cases (0-1) & $25 \pm 46$ \\
Compiling daily / weekly report to the Manager of Malaria Program in PHC (0-1) & $100 \pm 0$ \\
Provide information if there is a population migration / arrival of exodants from outside & \\
Java in the area (0-1) & $100 \pm 0$ \\
Assist malaria treatment following instructions from the PHC (0-1) & $100 \pm 0$ \\
Be present at the PHC for at least once a month (0-1) & $90 \pm 5.4$ \\
\hline Total &
\end{tabular}

Note: The score for each question ranges from negative attitude (minimum 1) to positive (maximum 4). A maximum practice points of 40 to a minimum of 0 . The total point is then converted into a score of 0-100.

Table 5. Characteristics of respondent $(\mathrm{N}=8)$

\begin{tabular}{|c|c|c|c|c|c|c|c|}
\hline Characteristics & $\mathbf{N}(8)$ & $\begin{array}{l}\text { Knowledge } \\
\text { score } \\
(\text { Mean } \pm \text { SD) }\end{array}$ & P-value & $\begin{array}{l}\text { Attitude } \\
\text { score } \\
(\text { Mean } \pm \text { SD) }\end{array}$ & P-value & $\begin{array}{l}\text { Practice } \\
\text { score } \\
(\text { Mean } \pm \text { SD) }\end{array}$ & P-value \\
\hline Age * & & & 0.23 & & 0.94 & & 0.52 \\
\hline $30-39$ & 2 & $80 \pm 9.4$ & & $52.5 \pm 3.5$ & & $91.6 \pm 11.8$ & \\
\hline $40-49$ & 4 & $77.5 \pm 4.2$ & & $52.5 \pm 3.5$ & & $90.6 \pm 2.1$ & \\
\hline$\geq 50$ & 2 & $71.6 \pm 2.4$ & & $51.3 \pm 5.3$ & & $87.5 \pm 5.9$ & \\
\hline Level of education** & & & 0.42 & & 0.52 & & 0.42 \\
\hline Primary-Secondary & 5 & $78 \pm 6.9$ & & $53 \pm 2.2$ & & $89.2 \pm 6.9$ & \\
\hline Tertiary & 2 & $73 \pm 0$ & & $51.3 \pm 2.2$ & & $91.6 \pm 0$ & \\
\hline Family income i* $^{*}$ & & & 0.84 & & 0.66 & & 0.67 \\
\hline$<\operatorname{IDR} 1,100,000$ & 5 & $75 \pm 2.4$ & & $51.3 \pm 5.3$ & & $91.6 \pm 0$ & \\
\hline$\geq \operatorname{IDR} 1,100,000$ & 2 & $65.3 \pm 5$ & & $53 \pm 3.2$ & & $90.1 \pm 6.2$ & \\
\hline Experience working as $M C W_{s}^{*}$ & & & 0.28 & & 0.55 & & 0.28 \\
\hline $0-10$ years & 4 & $77 \pm 4.2$ & & $52.5 \pm 3.5$ & & $92.7 \pm 5.2$ & \\
\hline $11-20$ years & 3 & $77 \pm 7.7$ & & $50.8 \pm 3.8$ & & $88.9 \pm 4.8$ & \\
\hline$>20$ years & 1 & 70 & & 55 & & 83 & \\
\hline \multicolumn{8}{|l|}{ Previous Training for $M C W \mathrm{~s}^{* *}$} \\
\hline Within 1 year & 2 & $75 \pm 2.4$ & 0.84 & $55 \pm 0$ & 0.19 & $93.8 \pm 8.8$ & 0.67 \\
\hline Within 2 years & 5 & $74.2 \pm 3.2$ & 0.42 & $53 \pm 3.8$ & 0.67 & $88 \pm 4$ & 0.14 \\
\hline Within 3 years & 4 & $78.3 \pm 5.8$ & 0.23 & $51.9 \pm 3.8$ & 0.88 & $88.5 \pm 4$ & 0.44 \\
\hline
\end{tabular}

*Kurskal Wallis Test, ** Mann Whitney Test. P-value $<0.05$

Table 6. Correlation between knowledge, attitude, and practice scores

\begin{tabular}{lcc}
\hline \multicolumn{1}{c}{ Variables } & Coefficient Correlation & P-value \\
\hline Knowledge-attitude & -0.42 & 0.30 \\
Knowledge-practice & -0.17 & 0.67 \\
Attitude-practice & -0.55 & 0.90 \\
\hline
\end{tabular}


score. The gender variable was not included because the sample consisted only of male.

\section{Correlation between knowledge, attitude, and practice}

Correlation is interpreted according to the following criteria: $0-0.25=$ weak correlation, $0.25-0.5=$ adequate correlation, $0.5-0.75=$ good correlation, greater than 0.75 $=$ very good correlation ${ }^{7}$. From the study results obtained a negative value on the correlation coefficient of the three variables. In addition, the significant correlation were not observed between knowledge, attitudes, and practice.

\section{DISCUSSION}

\section{Knowledge of MCW towards prevention and control of malaria}

This research was a pilot study to evaluate KAP of MCW towards malaria prevention and control. The results showed that the KAP scores were high and moderate for the knowledge and attitude of malaria prevention and control respectively. The mean score of knowledge was 77 \pm 5.6 which indicates high knowledge. The MCWs had the highest knowledge about the definition of malaria, while the lowest knowledge about the diagnosis and symptoms of malaria, as well as the main functions of MCW. These results were consistent with studies conducted in Batam ${ }^{10}$ and Mentawai ${ }^{11}$ which had a high knowledge score of malaria. In addition, a study in Rwanda (2016) showed that health cadres had a high knowledge scores for the definition of malaria ${ }^{12}$. Moreover, another study in Cameroon also showed low knowledge score about the diagnosis and symptoms of malaria ${ }^{13}$.

From the demographic data, there is no significant difference between knowledge and various demographic characteristics of age, education level, family income, experience working period as MCWs, and previous training for MCWs. In contrast to the study by Habimana, age and sex had a significant correlation to knowledge of malaria health cadres in Rwanda. However, the study in Rwanda also showed no significant relationship in education level and family income ${ }^{12}$. These results were probably due to the smaller sample size in this study compared to other studies. Additionally, the respondents that have fewer experience of working as MCWs, they compensated the fewer experience period by joined training for MCWs within 2 years thus had a high knowledge towards prevention and control of malaria.

\section{Attitude of $\mathrm{MCW}$ towards prevention and control of malaria}

The results of the study indicated that MCWs had moderate attitude scores towards malaria prevention and control. The attitude towards fogging as malaria prevention had a positive attitude. Meanwhile, the attitude towards malaria is a serious health problem, a good blood sample can facilitate to diagnose malaria, and malaria requires treatment to recover had a negative attitude value. This result was also supported by a study by Manalu in Batam which explains that there was a moderate attitude due to the perception that malaria is a common disease, so there is no need to seek treatment immediately if the community or family has malaria ${ }^{10}$.
This result shows a gap between knowledge and attitudes of MCW towards malaria prevention and control. This gap may caused by several factors, including a culture that is less supportive of malaria, so that despite having good knowledge, it still has not influenced the attitude of $\mathrm{MCW}^{10,14}$. A study by Supriati ${ }^{15}$ stated that one of determinant factor in prevention and control of malaria in Kulon Progo is the people's behavior which considers that malaria is not a life threatening disease. This behavior could lead to low prevention and control of malaria, and reduce the awareness of malaria management as a whole.

\section{Practice of $\mathrm{MCW}$ towards prevention and control of malaria}

This study found that all MCWs had good practice towards malaria prevention and control with a low practice of compiling daily/weekly reports to the malaria program manager in PHC. Likewise, a study in Cameroon showed that malaria health cadres had good practice towards malaria prevention and control ${ }^{13}$. The MCW evaluation study by Kusmanto also stated that the implementation of MCW activities in of case detection and treatment by MCW was well executed, but the supervision activities from the PHC were not optimized ${ }^{9}$. This result may be due to the long experience of respondents as being MCW and previous training for MCWs. Additionally, the respondents also always visits the PHC at least once a month to have coordination and meeting with the PHC's stakeholder about malaria prevention and control.

From the research, the significant association between KAP and demographic characteristics was not observed. There significant correlation between KAP knowledge, attitudes, and behavior also was not observed. These findings may due to the small sample size in the study.

\section{Research limitations}

There were number of limitations to this study, including the small sample size and the unvalidated questionnaire. The small samples size can cause bias so that it does not represent the general population. In addition, the questionnaire has not been validated so it is possible that it does not represent the variable being sought.

However, to the author's knowledge, this study is the first study that explore the KAP of MCWs in Indonesia. The results provided an understanding of the state of knowledge, attitude and practice among MCWs toward malaria control and prevention. Furthermore, as a pilot study, the data obtained through this research can be used to develop further and more in-depth research on KAP with a larger sample size

\section{CONCLUSION}

The study found that all MCWs had high knowledge scores, moderate attitudes, and good practice towards malaria prevention and control. Some aspects of low knowledge include diagnosis and symptoms of malaria, as well as the main tasks and functions of MCW. Meanwhile, negative attitudes and practice were seriousness towards malaria and compiling regular reports to the malaria program manager. There significant correlation was not observed between 
demographic characteristics and KAP MCW. Additionally, the significant correlation between knowledge, attitudes, and behavior also was not observed.

Thus, it is recommended for further studies on KAP of $\mathrm{MCW}$ towards malaria prevention and control with a larger sample size. As well as a more in-depth study of the factors that influence KAP MCW. In addition, regular training on $\mathrm{MCW}$ is also recommended to improve KAP MCW on malaria prevention and control.

\section{Acknowledgment}

The authors would like to express gratitude and appreciation to all parties who have been involved and supported this research, especially Puskesmas Kokap I and the late Dr. dr. Mahardika Agus Wijayanti, DTM \& H, M.Kes, who has guided the author during the research.

\section{Ethical Approval and Informed Consent}

The study was approved by the Ethics Committee of the Faculty of Medicine, Public Health and Nursing, Universitas Gadjah Mada with Ethical Clearance no.: KE $/ \mathrm{FK} / 1 / 65 / \mathrm{EC} / 2016$

\section{Funding}

This research includes the project 'PROMOTE: Kulon Progo Reduce Malaria through One Health Initiative' funded by INDOHUN (Indonesia One Health University Network).

\section{Conflict of Interest}

There is no conflict of interest in this study.

\section{REFERENCES}

1. Ministry of Health Indonesia. Indonesia Health Profile 2018. Jakarta: Ministry of Health Indonesia; 2019.

2. Dinas Kesehatan Kabupaten Kulon Progo. Profil Kesehatan Kabupaten Kulon Progo Tahun 2019 (Data 2018). Dinas Kesehatan Kabupaten Kulon Progo; 2019.

3. Suryaningtyas NH, Margarethy I, Salim M. ANALISIS DATA SPASIAL MALARIA DI KABUPATEN KULON PROGO TAHUN 2017. 11:9.

4. Sunguya BF, Mlunde LB, Ayer R, Jimba M. Towards eliminating malaria in high endemic countries: the roles of community health workers and related cadres and their challenges in integrated community case management for malaria: a systematic review. Malar J. 2017 Dec;16(1):10.

5. Murhandarwati EEH, Fuad A, Nugraheni MD, Sulistyawati, Wijayanti MA, Widartono BS, et al. Early malaria resurgence in pre-elimination areas in Kokap Subdistrict, Kulon Progo, Indonesia. Malar J. 2014 Dec;13(1):130
6. Menteri Kesehatan Republik Indonesia. Keputusan Menteri Kesehatan Republik Indonesia Nomor 293/MENKES/SK/IV/2009 tentang Eliminasi Malaria di Indonesia. Nomor 293/MENKES/SK/ IV/2009 Apr 28, 2009.

7. ul Haq N, Hassali MA, Shafie AA, Saleem F, Farooqui M, Aljadhey $\mathrm{H}$. A cross sectional assessment of knowledge, attitude and practice towards Hepatitis B among healthy population of Quetta, Pakistan. BMC Public Health. 2012 Aug 23;12(1):692.

8. Sugianti. Studi Evaluasi Cara Kerja Juru Malaria Desa (JMD) dalam Active Case Detection (ACD) di Wilayah Kerja Kecamatan Samigaluh Kabupaten Kulon Progo. [Semarang]: Universitas Dipenogoro; 2005.

9. Kusmanto. Evaluasi Pelaksanaan Penemuan dan Pengobatan Malaria oleh Juru Malaria Desa (JMD) pada Program Pemberantasan Malaria di Kabupaten Purworejo. [Semarang]: Universitas Dipenogoro; 2005.

10. Manalu HSP, Sukowati S. PENGETAHUAN, SIKAP DAN PERILAKU MASYARAKAT TERHADAP MALARIA DI KOTA BATAM. 2011;21:8.

11. Christy K, Tanumihardja TN, Handayani YS. Hubungan Pengetahuan dan Sikap tentang Malaria dengan Perilaku Pencegahan pada Kehamilan pada Ibu Hamil di Desa Muara Siberut dan Desa Maillepet, Mentawai, Indonesia. Cermin Dunia Kedokt. 2019 May 1;46(5):339-44.

12. Habimana A, Harerimana A, Asingizwe D, Nyandwi T, Njunwa KJ. Community Health Workers' knowledge, attitudes and practices about malaria prevention in Gicumbi District, Rwanda. Rwanda J. 2016 Nov 1;3(1):27

13. Shey N D, Clement AN J, N M, Wung B A, Ivo K K. Community Health Workers' Knowledge, Attitudes and Practices Regarding Malaria Control and Prevention in Bamenda, Cameroon: A Community Based Study. J Health Med Inform [Internet]. 2017 [cited 2020 Sep 9];08(05). Available from: https://www.omicsonline.org/open-access/ community-health-workers8217-knowledge-attitudes-and-practicesregarding-malaria-control-and-prevention-in-bamenda-cameroon-acomm-2157-7420-1000294-96347.html

14. Essé C, Utzinger J, Tschannen AB, Raso G, Pfeiffer C, Granado S, et al. Social and cultural aspects of 'malaria' and its control in central Côte d'Ivoire. Malar J. 2008 Oct 30;7(1):224.

15. Supriati T. Menuju Eliminasi Malaria Kab. Kulon Progo: pendekatan social behavior change communication (SBCC). In Yogyakarta; 2018. 